DOI: https://doi.org/10.31933/jimt.v3i2 Received: 6 September 2021, Revised: 15 Oktober 2021, Publish: 7 November 2021

JIMT
JURNAL ILMU MANAJEMEN
TERASTI

\title{
PENGEMBANGAN E-LEARNING PADA MATA PELAJARAN EKONOMI MENGGUNAKAN APLIKASI EDMODO KELAS XI IPS SMA NEGERI 11 KOTA JAMBI
}

\author{
Khairinal Khairinal ${ }^{1}$, Rosmiati Rosmiati ${ }^{2}$, M. Nanda Prayoga ${ }^{3}$ \\ 1) Universitas Jambi, Jambi, Indonesia, khairinal164@gmail.com \\ 2) Universitas Jambi, Jambi, Indonesia, rosmiati.fkip@unja.ac.id \\ 3) Universitas Jambi, Jambi, Indonesia, muhammad.nandaprayoga@gmail.com
}

\section{Korespondensi Penulis: M. Nanda Prayoga}

\begin{abstract}
Abstrak: Abad 21 merupakan abad pengetahuan dimana pengetahuan akan menjadi landasan utama segala aspek kehidupan. Abad pengetahuan sangat berpengaruh terhadap pendidikan, ilmu pengetahuan, teknologi, dan lapangan kerja. Pendidikan sangat terkait dengan aktivitas mulia manusia yang tugas utamanya adalah membantu pengembangan humanitas manusia untuk menjadi manusia yang berkepribadian mulia dan utama menurut karakteristik idealitas manusia yang diinginkan. Model penelitian pengembangan yang digunakan dalam penelitian ini adalah model pengembangan ADDIE yang terdiri dari analisis, desain, pengembangan, implementasi, dan evaluasi. Validator terhadap E-Learning ini terdiri dari validator materi dan validator media. Subjek ujicoba penelitian ini adalah siswa kelas XI IPS SMA Negeri 11 Kota Jambi. E-Learning dari segi desain memperoleh persentase kualitas $80 \%$ termasuk dalam kategori "baik" dan dari segi materi memperoleh persentase $80 \% \%$ termasuk dalam kategori "baik". Persentase respons siswa terhadap media berdasarkan hasil ujicoba yaitu 82,36\%. Dengan demikian, E-Learning mendapatkan respons yang sangat baik oleh siswa untuk digunakan sebagai bahan perbantuan pembelajaran Ekonomi di-SMA kelas XI pada materi Kerja sama Ekonomi Internasional. E-Learning ini dapat membantu guru dalam proses pembelajaran Ekonomi khususnya pada materi Kerja sama Ekonomi Internasional yang dapat membantu siswa mengetahui, dan memahami materi serta meningkatkan pengetahuan siswa dalam kegiatan pembelajaran Ekonomi.
\end{abstract}

Kata Kunci: E-Learning, Kerja sama Ekonomi Internasional, dan Aplikasi Edmodo

\section{PENDAHULUAN}

Abad 21 merupakan abad pengetahuan dimana pengetahuan akan menjadi landasan utama segala aspek kehidupan. Abad pengetahuan sangat berpengaruh terhadap pendidikan, ilmu pengetahuan, teknologi, dan lapangan kerja. Pendidikan sangat terkait dengan aktivitas mulia manusia yang tugas utamanya adalah membantu pengembangan humanitas manusia untuk menjadi manusia yang berkepribadian mulia dan utama menurut karakteristik idealitas manusia yang diinginkan. 
Kunci pembangunan masa mendatang bagi bangsa indonesia adalah pendidikan. Sebab dengan pendidikan diharapkan setiap individu dapat meningkatkan kualitas keberadaannya dan mampu berpartisipasi dalam gerak pembangunan. Dengan pesatnya perkembangan dunia di era globalisasi ini, terutama di bidang teknologi dan ilmu pengetahuan, maka pendidikan Nasional juga harus terus menerus di kembangkan seirama dengan zaman. Pada umumnya sebuah sekolah dan pendidikan bertujuan pada bagaimana kehidupan manusia itu harus di tata, sesuai dengan nilai-nilai kewajaran dan keadaban (civility). (Wahab, 2015: 77)

Memasuki abad ke-21, sistem pendidikan nasional menghadapi tantangan yang sangat kompleks dalam menyiapkan kualitas sumber daya manusia (SDM) yang mampu bersaing di era global. Upaya yang tepat untuk menyiapkan sumber daya manusia (SDM) yang berkualitas dan satu-satunya wadah yang dapat dipandang dan seyogianya berfungsi sebagai alat untuk membangun SDM yang bermutu tinggi adalah pendidikan.

Dalam rangka menghadapi tantangan pada abad 21 ini, setiap guru hendaknya memiliki kemampuan dan profesionalisme yang tinggi. Tantangan yang dihadapi guru pada abad 21 tidak lagi berkisar pada kemampuan akademik siswa, tetapi lebih pada pendidikan intelektual, emosional, moral dan akhlak siswa. Era globalisasi menuntut persaingan tinggi tanpa terkecuali bagi seluruh manusia. Tidak ada pilihan lain kecuali harus menghadapi abad yang serba kompleks ini. Guru profesional abad 21 bukanlah guru yang sekedar mampu mengajar dengan baik. Guru profesional abad 21 adalah guru yang mampu menjadi pembelajar sepanjang karir untuk peningkatan keefekfifan proses pembelajaran siswa seiring dengan perkembangan lingkungan, dapat berkomunikasi baik langsung maupun menggunakan teknologi secara efektif dengan orang tua murid untuk mendukung pengembangan sekolah.

Salah satu komponen penting dalam upaya meningkatkan mutu pendidikan nasional adalah adanya guru yang berkualitas, profesional, dan berpengetahuan. Guru, tidak hanya sebagai pengajar, namun guru juga mendidik, membimbing, mengarahkan, melatih, menilai, dan mengevaluasi peserta didik. Dalam menjalankan tugasnya sebagai agen pembelajaran. Guru yang profesional adalah guru yang menguasai materi pembelajaran, menguasai kelas dan mengendalikan perilaku anak didik, menjadi teladan, membangun kebersamaan, menghidupkan suasana belajar dan menjadi manusia pembelajar (learning person).

Pembelajaran di abad 21 ini juga, guru tidak hanya menggunakan metode ceramah tetapi juga guru harus dituntut lebih dari itu, apalagi di era ini khususnya tahun ini dunia mengalami pandemi global yaitu virus corona yang tidak memungkinkan bagi sekolah untuk melakukan kegiatan belajar dan pembelajaran dan harus menggunakan metode pembelajaran berupa video call pembelajaran yang menggunakan aplikasi zoom, google meet dan sebagainya, maka dari itu guru sebagai fasilitator dituntut harus bisa dalam mengoperasikan aplikasi zoom maupun google meet dalam pembelajaran berbasis online.

Penggunaan teknologi mobile mempunyai sumbangan besar dalam lembaga pendidikan, termasuk di dalamnya adalah pencapaian tujuan pembelajaran jarak jauh. Berbagai media juga dapat digunakan untuk mendukung pelaksanaan pembelajaran secara daring. Misalnya kelas-kelas virtual menggunakan layanan Google Classroom, Edmodo, dan Schoology dan applikasi pesan instan seperti WhatsApp.

Perkembangan teknologi sudah banyak memberi pengaruh terhadap cara hidup kita, salah satunya adalah dalam bidang pendidikan dengan penggunaan e-learning dalam kegiatan pembelajaran di sekolah maupun perguruan tinggi. Kelebihan yang ada yaitu dapat memberikan visual yang menarik baik gambar ataupun video untuk memperjelas pembelajaran. Namun belum tentu, belajar secara online mampu mengakomodasi semua kebutuhan siswa. Media pembelajaran berbasis internet atau E-Learning saat ini banyak 
digunakan untuk kegiatan belajar mengajar. Salah satu media yang dapat digunakan untuk menunjang kegiatan dalam pembelajaran yaitu Edmodo.

Edmodo adalah platform pembelajaran bagi guru, siswa dan sekolah berbasis sosial media. Edmodo menyediakan cara yang aman dan mudah bagi kelas untuk terhubung dan berkolaborasi, berbagi konten dan akses pekerjaan, nilai dan pemberitahuan sekolah. Edmodo membantu pendidik memanfaatkan kekuatan media sosial untuk menyesuaikan kelas untuk setiap peserta didik. Edmodo dapat membantu pendidik membuat sebuah kelas virtual berdasarkan pembagian kelas nyata di sekolah, dimana dalam kelas tersebut terdapat penugasan, kuis,dan pemberian nilai pada setiap akhir pembelajaran.

Edmodo adalah platform media sosial yang sering digambarkan seperti Facebook untuk sekolah dan dapat berfungsi lebih banyak lagi sesuai kebutuhan. Edmodo merupakan media yang menarik bagi pendidik dan peserta didik dengan elemen sosial yang menyerupai Facebook. Seorang pendidik dapat dengan mudah mengelola sebuah sistem yang menyediakan fitur terbaik dan praktis, sehingga pendidik selalu terhubung dengan peserta didik dan mengatur aktivitas peserta didik dengan mudah. Kegiatan pembelajaran yang dapat digunakan sesuai dengan fitur yang tersedia pada media. Edmodo yakni content sharing atau berbagi materi pelajaran, penugasan, kuis, polling serta memungkinkan adanya kegiatan diskusi pada fitur komentar.

Edmodo adalah jejaring sosial terbatas dengan guru sebagai pusatnya. Murid dapat masuk kedalam sebuah circle di Edmodo hanya apabila diundang oleh gurunya, karena itu peserta didik tahu bahwa orang-orang yang ada di circle tersebut hanyalah teman-teman sekelasnya. Semua orang di Edmodo adalah anonimus, termasuk guru. Edmodo merupakan social network berbasis lingkungan sekolah (school based environment) yang dikembangkan oleh Nicolas Borg and Jeff O'Hara, dengan fitur-fitur pendukung proses belajar mengajar. Edmodo dapat diakses bebas di www.edmodo.com oleh guru, siswa, maupun orangtua siswa. Bila dibandingkan dengan media sosial learning management system lainnya, edmodo memiliki beberapa kelebihan sebagai berikut: (1)Mirip facebook, mudah digunakan, (2)Closed group collaboration, hanya yang memiliki group code yang dapat mengikuti kelas, (3)Free diakses online, dan tersedia untuk perangkat smartphone, android dan iphone, (4)Tidak memerlukan server disekolah, (5)Dapat diakses dimanapun dan kapanpun, (6)Edmodo selalu diupdate oleh pengembang, (7)Edmodo dapat diaplikasikan dalam satu kelas, satu sekolah, antar sekolah dalam satu kota atau kabupaten, (8)Edmodo dapat digunakan bagi siswa, guru, dan orang tua, (9)Edmodo digunakan untuk berkomunikasi dengan menggunakan model sosial media, learning material, dan evaluasi, (10)Edmodo mendukung model team teaching, co-teacher, dan teacher, (11)Terdapat notifikasi, (12)Fitur badge dapat dimanfaatkan untuk meningkatkan motivasi siswa.

Berdasarkan hal tersebut maka pengembangan E-Learning ini diharapkan dapat menjadi bahan ajar yang menarik dan menyenangkan bagi siswa. Hal inilah yang mendasari penulis tertarik untuk melakukan penelitian yang berjudul "Pengembangan E-Learning Pada Mata Pelajaran Ekonomi Menggunakan Aplikasi Edmodo kelas XI Ips Sma Negeri 11 Kota Jambi"

Penelitian ini bertujuan untuk: 1) Pengembangan E-Learning berbasis Aplikasi Edmodo digunakan dalam pembelajaran ekonomi. 2) Menghasilkan produk menggunakan E-Learning berbasis Aplikasi Edmodo untuk mata pelajaran ekonomi. 3) Mengetahui respons siswa terhadap E-Learning berbasis Aplikasi Edmodo dalam pembelajaran ekonomi. 


\section{KAJIAN PUSTAKA}

\section{Learning Content Management System}

Learning Content Management System(LCMS) adalah sebuah sistem yang digunakan untuk membuat, menggunakan kembali, menempatkan, menyampaikan, mengelola, dan memperbaiki materi pembelajaran. Dengan LCMS diharapkan dapat disampaikan materi pembelajaran yang terpersonalisasi dalam bentuk objek pembelajaran.

Objek pembelajaran adalah materi pendidikan yang terdiri dari 4 komponen, yaitu tujuan pembelajaran (apa yang akan diperoleh dan dipahami oleh siswa selama pembelajaran berlangsung), materi pembelajaran yang dibutuhkan untuk mencapai tujuan tersebut, evaluasi untuk menilai apakah tujuan pembelajaran tercapai atau tidak, dan metadata yang menggambarkan isi/kandungan dari sebuah objek. Metadata biasanya berisi informasi mengenai educational content, seperti pemilik dari materi, bahasa yang digunakan untuk menulis materi, pengetahuan yang diperlukan untuk memahami suatu materi.

\section{Media Aplikasi Edmodo}

Edmodo adalah platform education network berbasis learning management system (lms) yang akan menghubungkan antara guru dan siswa (bahkan sampai orang tua) untuk melakukan pembelajaran secara online yang bisa diakses secara gratis. Edmodo merupakan salah satu hasil dari sebuah perkembangan teknologi informasi yang membantu dan menyongsong pendidikan abad 21 yang merupakan sebuah perusahaan yang memberikan layanan media sosial untuk mendukung sistem pembelajaran online bagi para pegiat pendidikan, seperti guru, siswa, mahasiswa, dosen. Di dalam platform Edmodo ini baik pengajar maupun siswanya dapat saling berinteraksi dengan mudah. Tentu hal ini akan mempermudah kegiatan-kegiatan pembelajaran seperti pemberian tugas, mengerjakan ujian, kuis, dan masih banyak lagi.

Platform atau aplikasi edmodo dicipkan oleh tiga orang yakni nic borg, jeff o'hara, crystal hutter pada 1 september 2008. Tidak hanya berkomunikasi, melalui platform ini guru bisa melakukan pembelajaran dengan membagikan konten (baik berupa teks atau video) latihan soal, sampai dengan pr (pekerjaan rumah). Berbeda dengan platform lain seperti ruangguru dan zenius yang lebih memfokuskan diri pada siswa yang ingin belajar, edmodo didesain untuk lebih fokus pada kebutuhan guru. Diaplikasi ini, terlebih dahulu guru akan membuat kelas online, lalu siswa maupun orang tua akan ikut didalamnya jika mendapatkan undangan dari pembuat kelas tersebut. Sederhananya, edmodo adalah sebuah kelas maya yang berbentuk website dan aplikasi yang akan memudahkan guru dalam mengatur pembelajaran secara online dengan berbagai tools serta fitur yang dihadirkan.

Adapun fitur-fitur dari Aplikasi Edmodo yaitu, 1) Parent Code. 2) Award Badge. 3) Polling. 4) Assigment. 5) Gradebook. 6) Quiz. 7) File dan Link. Adapun kelebihan dari aplikasi edmodo ini, 1) Memiliki tampilan yang sangat ramah dan hampir mirip seperti sosial media, bahkan beberapa orang menyebutnya sebagai facebooknya guru dan siswa untuk belajar online. 2) Memiliki tampilan yang sangat ramah dan hampir mirip seperti sosial media, bahkan beberapa orang menyebutnya sebagai facebooknya guru dan siswa untuk belajar online. 3) Memiliki tampilan yang sangat ramah dan hampir mirip seperti sosial media, bahkan beberapa orang menyebutnya sebagai facebooknya guru dan siswa untuk belajar online.

Adapun langkah-langkah dalam menggunakan Aplikasi Edmodo adalah sebagai berikut: 


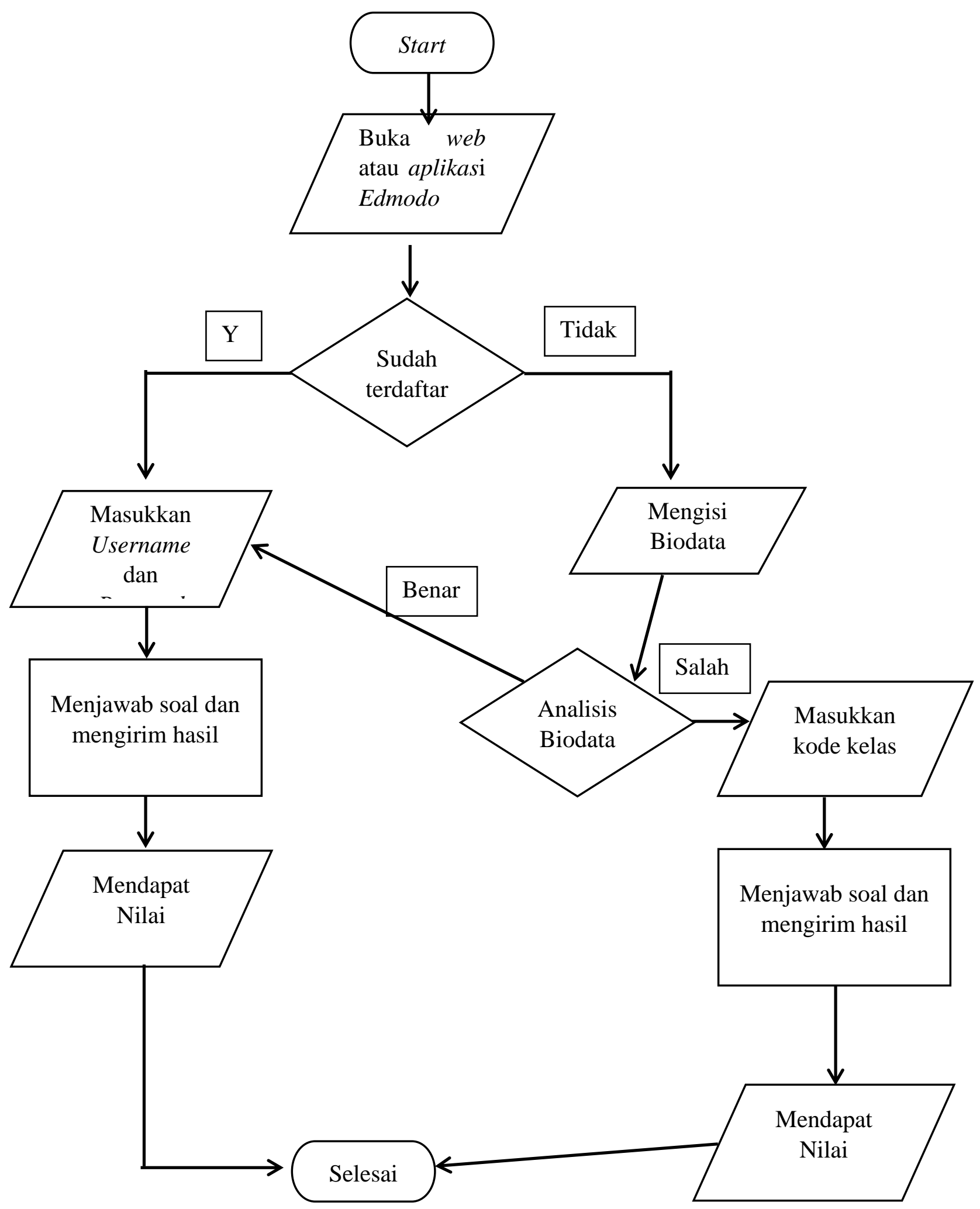

Gambar 1. Flowchart Edmodo 


\section{METODE PENELITIAN}

Model penelitian yang peneliti gunakan model pengembangan ADDIE yang dikembangkan untuk merancang sistem pembelajaran. ADDIE merupakan singkatan dari Analysis, Design, Development or Production, Implementation or delivery and Evaluations. Instrumen pengumpulan data yang peneliti pakai ada dua, yaitu: Kuisioner dan wawancara. 1) Kuisioner Menurut Sugiyono (2013: 199) kuesioner merupakan teknik pengumpulan data yang dilakukan dengan cara memberi seperangkat pertanyaan atau pernyataan tertulis kepada responden untuk dijawab. 2) Wawancara merupakan salah satu metode pengumpulan data dan informasi yang dilakukan secara lisan. Proses wawancara dilakukan dengan cara tatap muka langsung atau by phone. Selama wawancara ini petugas pengambil data mengajukan pertanyaan, meminta penjelasan dan jawaban kepada responden secara lisan, mencatat jawaban yang penting, atau merekam suara proses wawancara berlangsung. (Mulyatingsih. 2014: 32).

Teknik analisis data dalam penelitian ini melalui lembar penilaian kevalidan yang akan dinilai oleh ahli materi dan ahli media. Validasi adalah ukuran yang menunjukkan tingkat-tingkat kevalidan atau kesahihan suatu instrumen. Suatu instrumen yang valid dan sahih mempunyai validitas yang tinggi namun sebaliknya instrumen yang kurang valid memiliki validitas yang rendah.

\section{HASIL DAN PEMBAHASAN}

Berdasarkan pengembangan e-learning berbasis aplikasi edmodo pada mata pelajaran ekonomi kelas XI IPS SMA NEGERI 11 Kota Jambi yang telah melalui proses validasi, dan penelitian, maka dapat diperoleh hasil sebagai berikut: 1) Hasil validasi produk berupa validasi oleh ahli media dan oleh ahli materi terhadap desain dan isi materi E-Learning yang dikembangkan. 2) Hasil ujicoba kelas XI IPS di SMA Negeri 11 Kota Jambi. Ujicoba berupa angket sebanyak 15 angket yang di isi oleh siswa kelas IPS 2. 3) Produk pembelajaran $E$ Learning pembelajaran Berbasis Aplikasi Edmodo yang bisa digunakan dalam pembelajaran di SMA kelas XI IPS 2.

Tahap Analisis yang dilakukan dalam penelitian ini adalah melihat potensi dan masalah. Berdasarkan hasil observasi yang dilakukan peneliti di SMA Negeri 11 Kota Jambi diperoleh informasi bahwa sekolah telah dilengkapi fasilitas teknologi penunjang aktifitas belajar siswa meliputi sarana dan prasarana pendukung Information Communication and Technology (ICT) yang memadai seperti Lab computer, Liquid Crystaal Display Projector (LCD projector), Android dan jaringan internet.

Tahap Desain E-learning berbasis aplikasi edmodo pada mata pelajaran ekonomi kelas XI IPS SMA Negeri 11 Kota Jambi meliputi beberapa tahap, yaitu sebagai berikut: 1) Jadwal pembuatan E-Learning, Pembuatan produk dimulai dari menganalisis E-Learning yang akan dikembangkan, mengumpulkan bahan dan membuat E-Learning yang diperkirakan membutuhkan waktu 3 bulan. 2) Spesifikasi produk pengembangan, Spesifikasi E-Learning berbasis Aplikasi Edmodo yang dihasilkan dapat dijelaskan sebagai berikut: A) Produk yang dihasilkan berupa E-Learning dengan penggunaan Power Point sebagai penunjang ELearning agar lebih mudah di pahami siswa. B) Produk menggunakan aplikasi Edmodo. C) Materi yang digunakan adalah materi Kerjasama Ekonomi Internasional kelas XI IPS.

Tahap Pengembangan Tahap pengembangan merupakan tahap rancangan produk yang siap untuk dimplementasikan. Bentuk rancangan produk meliputi: 1) Pembuatan E-LEarning dari awal hingga akhir. 2)Membuat angket validasi ahli materi dan validasi ahli media dan 
angket untuk siswa. 3) Validasi produk oleh ahli materi yaitu Dr. Drs. Suratno, M.Pd dan ahli media yaitu Dr. Sofyan, M.Pd untuk menilai kelayakan produk yang telah dikembangkan.

Adapun hasil validasi dari ahli materi yaitu sebesar $80 \%$ yang dapat dikatakan sangat baik begitupun dengan hasil validasi dari ahli media di dapat sebesar $80 \%$ juga dan sangat baik, setelah mendapatkan hasil validasi dari kedua ahli kemudian peneliti melakukan penelitian ke siswa dan di dapatkan berupa hasil dari total sebesar 82,36\% dikategorikan sangat baik juga.

\section{KESIMPULAN DAN SARAN}

Kesimpulan: 1) Pengembangan dilakukan dengan beberapa tahap yang dilalui dari dimulai dengan mengumpulkan bahan dan materi. Validasi oleh beberapa ahli yaitu, ahli media dan ahli materi dan juga ujicoba terhadap siswa. Hasil ujicoba siswa di dapatkan berupa hasil persentase sebesar $82,36 \%$ dengan kategori sangat baik yang berarti pengembangan $E$ Learning ini layak digunakan bagi siswa. Validasi media memperoleh persentase sebesar $80 \%$ dan hasil validasi materi memperoleh persentase sebesar $80 \%$ dengan demikian berdasarkan hasil kedua validasi tersebut e-learning yang dikembangkan dapat dikatakan layak untuk diujicobakan. 2) Dengan bantuan flowchart dapat memudahkan siswa dalam mengetahui cara menggunakan aplikasi Edmodo serta saya lampirkan cara login, cara mengirim tugas pada bagan setelah pembuatan flowchart sehingga dapat memudahkan siswa. 3) Respon siswa pada aplikasi edmodo sangat menyenangkan dan mudah digunakan dengan ujicoba siswa mereka sangat menyukai pembelajaran via e-learning ini dengan persentase respon siswa sebesar $82,36 \%$

Saran: 1) E-learning ini dapat membantu guru dalam pembelajaran khususnya mata pelajaran ekonomi. 2) E-learning ini dapat membantu motivasi dan semangat belajar siswa khususnya pada mata pelajaran ekonomi. 3) Penelitian ini dapat dijadikan masukan untuk guru agar menjadi pembelajaran yang lebih menarik lagi.

\section{DAFTAR RUJUKAN}

Agus Rahmadi, Rosadi Muhammad Edya, Dewi Suzana. (2015). Penerapan System ELearning Dengan Edmodo Pada Pengajar Untuk Penunjang System Pengajaran Di Mtsn Kelayan Banjarmasin. Jurnal Al-Ikhlas,Volume 1 Nomor 1, September 2015 ISSN 2461-0992

Andrianai, Dwi Esti. (2010). Mengembangkan Profesionalitas Guru Abad 21 Melalui Program Pembimbingan yang Efektif. Jurnal Manajemen Pendidikan. No.2.

Ayuningtyas Vinanda U'un. (2018). Penerapan Media Pembelajaran Edmodo Untuk Meningkatkan Motivasi Aktivitas Intelektual Pada Mahasiswa Pendidikan Teknik Elektro Universitas Pgri Madiun. Jurnal PTK, Vol. 1, No. 2 Mei 2018 P-ISSN: 26213273 E-ISSN: 2621-1548

Arifin Muzayyin. (2003). Kapita Selekta Pendidikan Islam. Jakarta: Bumi Aksara.

Basir Muhammad. (2017). Pendekatan Pembelajaran. Sengkang. Lampena Intimedia

Dick, W. and Carey, L. (1985). The Systematic Design of Instruction. United States of America: Harper Collins Publishers.

Dick, W. and Carey, L. (2005). The Systematic Design of Instruction. United States of America: Harper Collins Publishers.

Fosnot. (1996). Enquiring teachers, enquiring learners: A constructivist approach for teaching. New York: Columbia University.

Kartini Kartono. (1990). Psikologi Perkembangan Anak. Bandung: CV. Mandar 
Kemp, Jerrold E. (1995). Instruction Desigen: A Plan for Unit and Course Development. Belmon: Feron.

Khadijah, Nyayu. (2006). Psikologi Belajar. Palembang: IAIN Raden Patah Press

Khodijah, N. (2016). Psikologi Pendidikan. Jakarta: RajaGrafindo Persada.

Muhaimin. (2002). Paradigma Pendidikan Islam (Upaya Mengefektifkan PAI di Sekolah). Bandung: Remaja Rosda Karya.

Mulyatiningsih, E. (2014). Metode Penelitian Terapan Bidang Pendidikan. Bandung: Alfabeta.

Nichols Jennifer. (2013). 4 Essential Rules of 21st Century Learning. [Online]. Tersedia di: http://www.teachthought.com/learning/4-essential-rules-of-21stcentury-learning/.

Diakses 15 Desember 2020

Pannen \& Purwanto. (2001). Penulisan Bahan Ajar. Jakarta. Depdiknas.

Rusman. (2017). Belajar dan pembelajaran: Berorientasi Standar Proses Pendidikan. Jakarta. Kencana

Safitri Meilani. (2020). Penerapan Edmodo Dalam Pembelajaran Matematika Untuk Melatih Kemandirian Belajar Siswa. Prosiding Seminar Nasional Pendidikan Program Pascasarjana Universitas Pgri Palembang 10 Januari 2020

Setyosari, P. (2012). Metode Penelitian dan Pengembangan. Jakarta: Kencana.

Soemanto, Wasty. (2006). Psikologi Pendidikan. Jakarta: Rineka Cipita.

Sugiyono. (2013). Metode Penelitian Pendidikan. Bandung: Alfabeta.

Suparno, M. Y. (2009). Keterampilan Dasar Menulis. Jakarta: Universitas Terbuka.

Suwarno Lalu. (2017). Penerapan Model Pembelajaran Berpikir Melalui Pertanyaan (Pbmp) Dengan Media Online Edmodo Dapat Meningkatkan Penguasaan Konsep Siswa Dalam Pelajaran Ipa Pada Pokok Bahasan Sistem Tata Surya Pada Siswa Kelas Viii Di Smp Negeri 2 Mataram. Jime, Vol. 3. No. 2 Oktober 2017 ISSN 2442-9511

Wahab, R. (2015). Psikologi Belajar. Jakarta: RajaGrafindo Persada.

Zainudin, Pambudi Buyung. (2019). Efektifitas Penerapan Perangkat Pembelajaran Fisika Dasar Berbasis Keterampilan Berpikir Kritis Menggunakan Aplikasi Edmodo Berplatform Android. Prisma Sains: Jurnal Pengkajian Ilmu dan Pembelajaran Matematika dan IPA IKIP Mataram June 2019. Vol. 7, No. 1 p-ISSN: 2338-4530 eISSN: 2540-7899 pp. 17-26 